\title{
Bioaccumulation of Heavy Metal Toxicity in the Vegetables of Mahalgaon, Nagpur, Maharashtra (India)
}

\author{
A. S. MAHAKALKAR ${ }^{1}$, R. R. GUPTA ${ }^{2}$ and S. N. NANDESHWAR ${ }^{3}$ \\ 'Sevadal Mahila Mahavidyalaya,Sakkaradara Square, Nagpur - 09, India. \\ ${ }^{2}$ Mohota Science College,Sakkaradara Square, Nagpur - 09, India. \\ ${ }^{3}$ Sevadal Mahila Mahavidyalaya,Sakkaradara Square, Nagpur - 09, India.
}

http://dx.doi.org/10.12944/CWE.8.3.16

(Received: October 03, 2013; Accepted: November 17, 2013)

\begin{abstract}
Mahalgaon is a village in Kamptee Taluka, Nagpur district of Maharashtra state, India. Most of the village formers from this village are engaged in vegetable cultivation and the village serves as one of the main supplier of vegetables required in the Nagpur market. All the fields and farms of this region are irrigated by the Nag river water which is highly polluted by urban waste and heavy metals. The purpose of this study was to study the bioaccumulation of heavy metals i.e. $\mathrm{Cu}, \mathrm{Mn}$, $\mathrm{Fe}, \mathrm{Zn}, \mathrm{Ni}$ and $\mathrm{Pb}$ in Water, Soil and Vegetables irrigated by Nag River water and to evaluate the level of bioaccumulation of the metals by the different vegetables. For this study five farms were selected in the Mahalgaon region. Each farm was situated near the bank of Nag River. The sampling was carried out according to grab method as given in APHA for the sampling of water, soil and vegetables. The concentration of heavy metals $(\mathrm{Cu}, \mathrm{Mn}, \mathrm{Fe}, \mathrm{Zn}, \mathrm{Ni}, \mathrm{Pb})$ were analyzed using Atomic Absorption Spectrophotometer (AAS). It was found that in water the concentration of Iron and zinc was highest whereas conc. of Nickel and lead was lowest. The concentration of $\mathrm{Fe}$ and $\mathrm{Zn}$ in the soil samples was very high compared to the WHO/FAO maximum permissive limits while the concentrations of $\mathrm{Cu}$ and $\mathrm{Mn}$ were slightly above the permissible limits. The concentration of $\mathrm{Pb}$ and $\mathrm{Ni}$ were below the detection limits in soil. On the other hand in all the vegetables, the concentration of heavy metals was higher than the WHO/FAO permissible limits. the soil-plant transfer factor of different heavy metals shows the following order- TFZn> $\mathrm{TF}_{\mathrm{Fe}}>\mathrm{TF}_{\mathrm{Cu}}>\mathrm{TF}_{\mathrm{Ni}}>\mathrm{TF}_{\mathrm{Mn}}>\mathrm{TF}_{\mathrm{Pb}}$.
\end{abstract}

Key words: Bioaccumulation, Heavy Metals, Temasna, Nag River, Vegetables.

\section{INTRODUCTION}

Mahalgaon is a village in Kamptee Taluka, Nagpur district of Maharashtra state, India'. Nag River is the main river which flows through the city and passes through Mahalgaon village hence it is the easiest and cheapest source of water for irrigation to the villagers on the bank of this river. The river serves as the drainage for the city and is highly polluted by urban waste and heavy metals ${ }^{2}$.

Most of the village formers are engaged in vegetable cultivation and the village serves as one of the main supplier of vegetables required in the Nagpur market. All the fields and farms are irrigated by the Nag river water.

Although trace quantities of certain heavy metals such as Chromium, Cobalt, Cupper, Manganese, Zinc etc. are essential micronutrients for higher animals and plant growth but their high concentration may cause health problem ${ }^{3,4}$ hence lot of work has been carried out to assess heavy metal bioaccumulation in different vegetables and plants $5,6,7,8,9,10,11,12$ which show that heavy metals are non-biodegradable and persistent environmental contaminants which are deposited on the surfaces and then absorbed into the tissues 
of vegetables. Plants take up heavy metals by absorbing them from contaminated soil.

By consumption of vegetables heavy metals enter the food chain ${ }^{8}$ and if consumed in high concentration it may lead to the chronic accumulation of heavy metals in the kidney and liver of humans causing disruption of biochemical processes leading to cardiovascular, nervous, kidney and bone disease $e^{8,13}$.

The purpose of this study was to study the bioaccumulation of heavy metals i.e. $\mathrm{Cu}, \mathrm{Mn}, \mathrm{Fe}$, $\mathrm{Zn}, \mathrm{Ni}$ and $\mathrm{Pb}$ in Water, Soil and Vegetables irrigated by Nag River water and to evaluate the level of bioaccumulation of the metals by the different vegetables. These are the most toxic heavy metals in water, soil and vegetables.

\section{MATERIAL AND METHODOLOGY}

Analytical reagent (AR) grade chemicals and distilled water were used throughout the study.

The sampling was carried out according to grab method as given in APHA for the sampling of water ${ }^{14}$, soil and vegetables. Five farms were selected in the Mahalgaon region for study purpose. Each farm was situated near the bank of Nag River.

\section{Water sampling}

Water samples were collected from five sites along Nag River at Mahalgaon. All the sampling sites were adjacent to the farms which were selected for study purpose. Sampling was made in the summer 2013. The containers used for

Table 1: Concentration (mg/l) of Heavy Metals in water samples.

\begin{tabular}{lcccccc}
\hline Sites & $\mathbf{C u}$ & $\mathrm{Mn}$ & $\mathrm{Fe}$ & $\mathbf{Z n}$ & $\mathrm{Ni}$ & $\mathbf{P b}$ \\
\hline 1 & 0.63 & 0.91 & 4.67 & 4.62 & 0.51 & 0.23 \\
2 & 0.65 & 0.92 & 4.65 & 4.6 & 0.53 & 0.25 \\
3 & 0.61 & 0.9 & 4.66 & 4.63 & 0.51 & 0.24 \\
4 & 0.63 & 0.91 & 4.69 & 4.62 & 0.5 & 0.22 \\
5 & 0.63 & 0.91 & 4.68 & 4.63 & 0.5 & 0.21 \\
Min & 0.61 & 0.9 & 4.65 & 4.6 & 0.5 & 0.21 \\
Max & 0.65 & 0.92 & 4.69 & 4.63 & 0.53 & 0.25 \\
Ave & 0.63 & 0.91 & 4.67 & 4.62 & 0.51 & 0.23 \\
\hline
\end{tabular}

water sampling were plastic bottles which were thoroughly washed with nitric acid followed by double distilled water. $2 \mathrm{ml}$ nitric acid was added in 1 liter water sample for the digestion of heavy metals and it was stored at cold temperature till the further analysis.

The concentration of heavy metals $(\mathrm{Cu}$, $\mathrm{Mn}, \mathrm{Fe}, \mathrm{Zn}, \mathrm{Ni}, \mathrm{Pb})$ were analyzed using Atomic Absorption Spectrophotometer (AAS SL-243 ELICO).

\section{Soil sampling}

Soil samples were collected from five sites. Each farm was first subdivided into five parts (four cornors and one centre) and then soil was collected from all the five spots and mixed together to get a composite soil sample from one field. Likewise all the five samples were collected. Sampling was carried out by using plastic equipment instead of metal tool to avoid any cross contamination. The samples were collected in a self locking polythene bags and were sealed so as to avoid any kind of loss or leakage. The soil samples were air dried and then disaggregated with mortar and pestle and dried samples were finely powdered to $2 \mathrm{~mm}$ thick sieve to make the sample homogeneous.

\section{Vegetables}

The vegetables selected for heavy metal analysis were Brinjal (Solanum Melongena), Flower, Bathua (Chenopodium Album), Chawli (Vigna Catjang), Spinach (Spinacia Oleraceae). All this are the common vegetables which are repeatedly consumed by peoples of this area. Grab method was used for collecting vegetable samples.

Table 2: Concentration $(\mathrm{mg} / \mathrm{g})$ of Heavy Metals in Soil samples.

\begin{tabular}{lcccccc}
\hline Site & Cu & Mn & Fe & Zn & Ni & Pb \\
\hline 1 & 0.42 & 0.69 & 11.08 & 2.85 & 0.11 & 0.083 \\
2 & 0.4 & 0.67 & 11.09 & 2.86 & 0.09 & 0.084 \\
3 & 0.43 & 0.68 & 11.09 & 2.88 & 0.13 & 0.081 \\
4 & 0.44 & 0.7 & 11.06 & 2.84 & 0.1 & 0.085 \\
5 & 0.41 & 0.71 & 11.08 & 2.82 & 0.12 & 0.082 \\
Min & 0.4 & 0.67 & 11.06 & 2.82 & 0.09 & 0.081 \\
Max & 0.44 & 0.71 & 11.09 & 2.88 & 0.12 & 0.085 \\
Ave & 0.42 & 0.69 & 11.08 & 2.85 & 0.11 & 0.083 \\
\hline
\end{tabular}


The plant samples were put through a three step washing sequence, which involved agitating and rinsing first in $0.1 \%$ teepol for 15 seconds, followed by $0.1 \% \mathrm{HCl}$ for 15 seconds and lastly three separate washes in deionised water.
The clean vegetable samples were air dried, weighed and placed in a dehydrator at $70{ }^{\circ} \mathrm{C}$ for 48-72 hours depending on sample size. Dried samples were weighed and mechanically ground using a stainless steel grinder $(<1 \mathrm{~mm})$ for digestion.

Table 3: Concentration $(\mathrm{mg} / \mathrm{g})$ of Heavy Metals in Vegetables

\begin{tabular}{|c|c|c|c|c|c|c|c|}
\hline & Vegtables & $\mathrm{Cu}$ & Mn & $\mathrm{Fe}$ & $Z n$ & $\mathbf{N i}$ & $\mathrm{Pb}$ \\
\hline \multirow{5}{*}{ Site-I } & Brinjal & 0.002 & 0.005 & 2.35 & 1.06 & 0.005 & 0.001 \\
\hline & Flower & 0.002 & 0.004 & 2.21 & 1.1 & 0.004 & 0.002 \\
\hline & Bathua & 0.001 & 0.002 & 1.68 & 1.69 & 0.004 & 0.001 \\
\hline & Chawli & 0.003 & 0.001 & 2.63 & 0.83 & 0.003 & 0.001 \\
\hline & Spinach & 0.002 & 0.004 & 2.43 & 1.52 & 0.006 & 0.004 \\
\hline \multirow{5}{*}{ Site-II } & Brinjal & 0.001 & 0.002 & 1.93 & 0.98 & 0.003 & 0.002 \\
\hline & Flower & 0.001 & 0.003 & 2.43 & 1.15 & 0.007 & 0.003 \\
\hline & Bathua & 0.002 & 0.002 & 2.22 & 1.1 & 0.008 & 0.001 \\
\hline & Chawli & 0.003 & 0.002 & 2.65 & 0.86 & 0.002 & 0.001 \\
\hline & Spinach & 0.003 & 0.001 & 1.2 & 1.04 & 0.007 & 0.003 \\
\hline \multirow{5}{*}{ Site-III } & Brinjal & 0.002 & 0.004 & 1.34 & 1.46 & 0.005 & 0.001 \\
\hline & Flower & 0.001 & 0.002 & 2.52 & 0.65 & 0.004 & 0.001 \\
\hline & Bathua & 0.004 & 0.003 & 2.37 & 1.88 & 0.006 & 0.001 \\
\hline & Chawli & 0.002 & 0.003 & 2.64 & 0.83 & 0.003 & 0.002 \\
\hline & Spinach & 0.001 & 0.002 & 2.44 & 1.36 & 0.003 & Nil \\
\hline \multirow{5}{*}{ Site-IV } & Brinjal & 0.002 & 0.001 & 3.04 & 1.11 & 0.006 & 0.004 \\
\hline & Flower & 0.003 & 0.002 & 1.95 & 1.24 & 0.006 & 0.001 \\
\hline & Bathua & 0.004 & 0.003 & 2.07 & 1.04 & 0.004 & 0.003 \\
\hline & Chawli & 0.002 & 0.004 & 2.63 & 0.82 & 0.002 & 0.001 \\
\hline & Spinach & 0.002 & 0.003 & 2.43 & 1.46 & 0.005 & 0.002 \\
\hline \multirow{5}{*}{ Site-V } & Brinjal & 0.003 & 0.003 & 1.34 & 1.43 & 0.006 & 0.002 \\
\hline & Flower & 0.003 & 0.006 & 1.36 & 0.93 & 0.005 & 0.002 \\
\hline & Bathua & 0.001 & 0.003 & 1.82 & 1.43 & 0.002 & 0.002 \\
\hline & Chawli & 0.001 & 0.003 & 2.67 & 0.85 & 0.003 & 0.001 \\
\hline & Spinach & 0.003 & 0.002 & 1.78 & 1.26 & 0.005 & 0.001 \\
\hline \multirow{5}{*}{ Average } & Brinjal & 0.002 & 0.003 & 1.99 & 1.208 & 0.005 & 0.002 \\
\hline & Flower & 0.002 & 0.0034 & 2.095 & 1.014 & 0.0052 & 0.0018 \\
\hline & Bathua & 0.002 & 0.0026 & 2.032 & 1.428 & 0.0048 & 0.0016 \\
\hline & Chawli & 0.0022 & 0.0026 & 2.63 & 0.838 & 0.0026 & 0.0012 \\
\hline & Spinach & 0.0022 & 0.0024 & 2.056 & 1.328 & 0.0052 & 0.002 \\
\hline
\end{tabular}

Table 4: Soil-plant Transfer factor (TF) of vegetables

\begin{tabular}{lcccccc}
\hline Veg. & $\mathbf{T F}_{\mathrm{Cu}}$ & $\mathbf{T F}_{\mathrm{Mn}}$ & $\mathbf{T F}_{\mathrm{Fe}}$ & $\mathbf{T F}_{\mathrm{Zn}}$ & $\mathbf{T F}_{\mathrm{Ni}}$ & $\mathbf{T F}_{\mathrm{Pb}}$ \\
\hline Brinjal & 0.0048 & 0.0043 & 0.179 & 0.358 & 0.045 & 0.0241 \\
Flower & 0.0048 & 0.0049 & 0.189 & 0.356 & 0.047 & 0.0217 \\
Bathua & 0.0048 & 0.0038 & 0.183 & 0.501 & 0.043 & 0.0193 \\
Chawli & 0.0052 & 0.0038 & 0.237 & 0.294 & 0.024 & 0.0145 \\
Spinach & 0.0052 & 0.0035 & 0.185 & 0.466 & 0.047 & 0.0241 \\
\hline
\end{tabular}


Table 5: Permissible limits of heavy metals given by IS/WHO/FAO ${ }^{15}$

\begin{tabular}{lcccccc}
\hline Heavy Metals & $\mathbf{C u}$ & $\mathbf{M n}$ & $\mathbf{F e}$ & $\mathbf{Z n}$ & $\mathbf{N i}$ & $\mathbf{P b}$ \\
\hline Water $(\mathrm{ml} / \mathrm{l})$ & $0.05-1.5$ & $0.01-0.5$ & $0.03-1.0$ & $5.0-10.0$ & 0.2 & $0.1-0.1$ \\
Soil $(\mathrm{mg} / \mathrm{g})$ & 0.270 & - & - & 0.600 & 0.075 & 0.006 \\
Crops $(\mathrm{mg} / \mathrm{g})$ & 0.001 & 0.003 & 0.003 & 0.001 & 0.001 & 0.001 \\
\hline
\end{tabular}

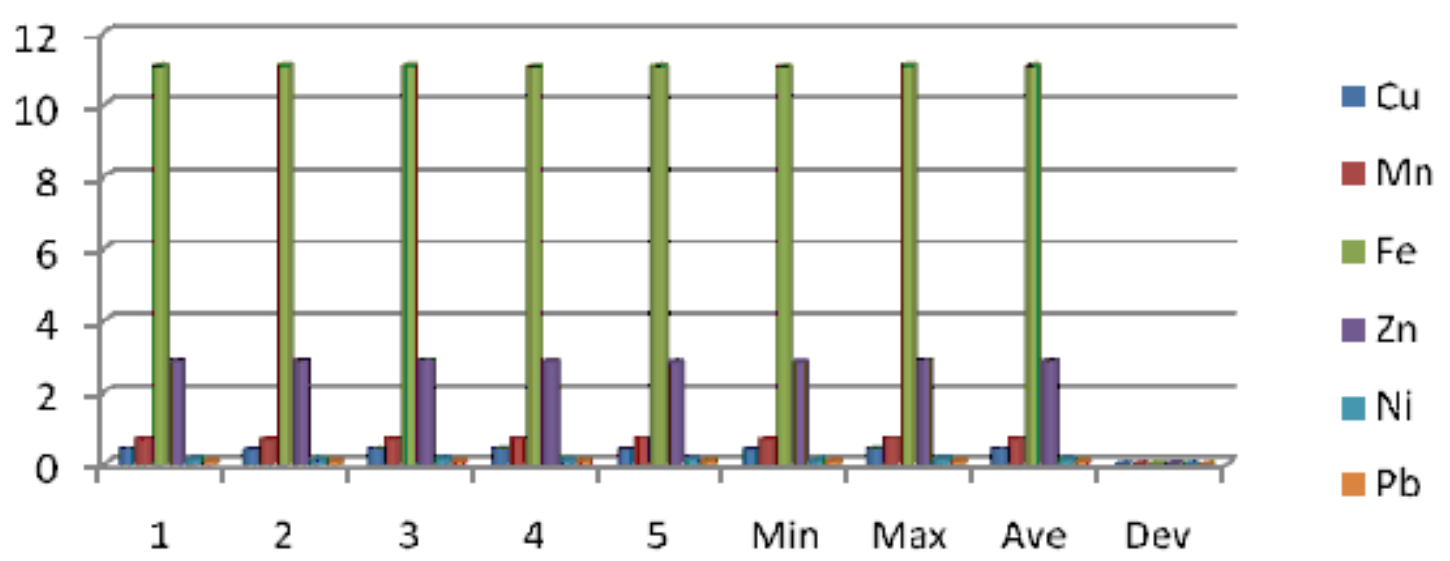

Fig.1: Concentration of Heavy metals in soil samples

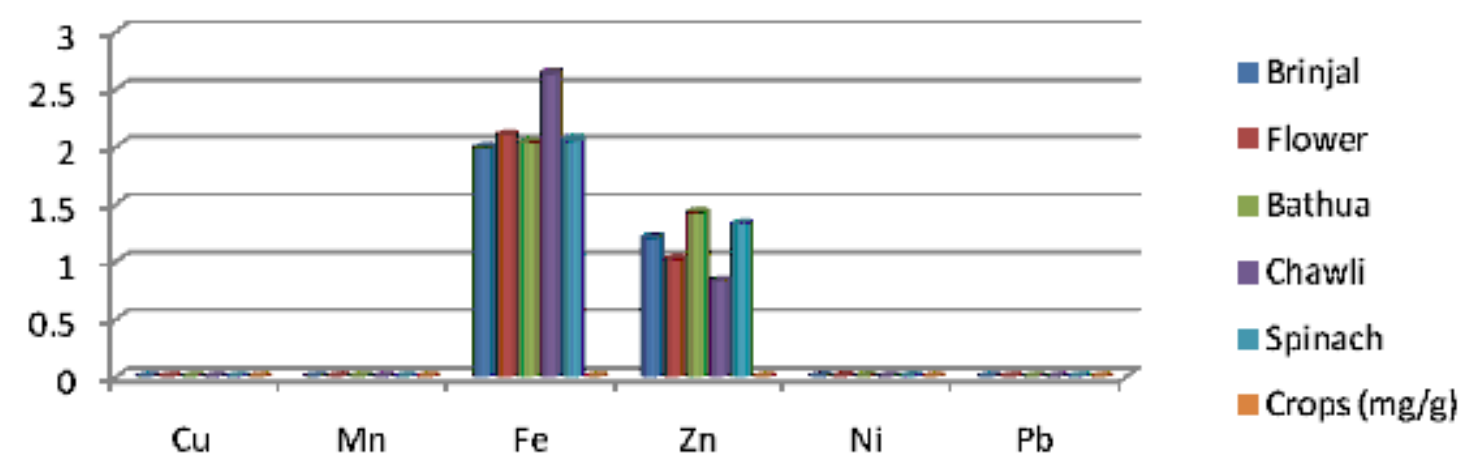

Fig. 2: Comparison of Heavy metal concentration of different vegetables with the permissible limit

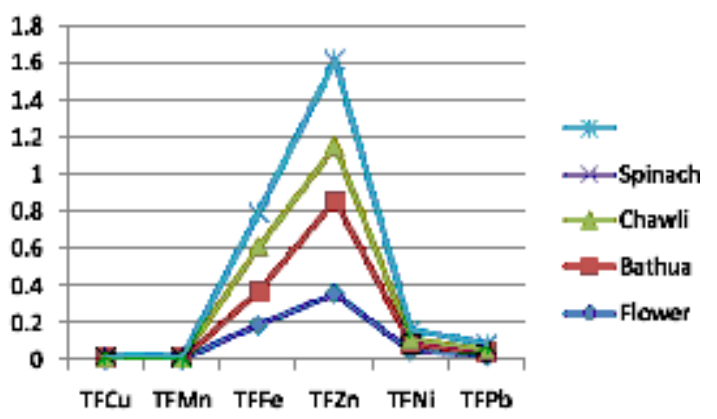

Fig. 3: Transfer factor of Heavy metals from oil to vegetables
A portion of the dry vegetable powder material was digested in a mixture of $\mathrm{HNO}_{3}$ and perchloric acid $\left(\mathrm{HClO}_{4}\right)$. The extracts were analyzed for various elements using AAS.

\section{RESULT AND DISCUSSION}

The concentrations of the heavy metals $(\mathrm{ml} / \mathrm{l}$ and $\mathrm{mg} / \mathrm{g})$ in water, soil and vegetables are given in tables 1, 2, 3 respectively.

In water the concentration of Iron and zinc was highest whereas concentration of Nickel and lead was lowest. 
Table 2 shows that the city farm soil were moderately enriched in $\mathrm{Cu}, \mathrm{Mn}$ and $\mathrm{Ni}$, but strongly enriched with $\mathrm{Fe}$ and $\mathrm{Zn}$ may be due to anthropogenic contributions. The concentration of $\mathrm{Cu}, \mathrm{Mn}, \mathrm{Fe}, \mathrm{Zn}, \mathrm{Ni}, \mathrm{Pb}$ in soil varied from 0.40-0.44; $0.67-0.71 ; 11.06-11.09 ; 2.82-2.88 ; 0.09-0.13 ; 0.081-$ $0.085 \mathrm{mg} / \mathrm{g}$ respectively at different sites. Similar results are also reported by Tomar et. al, 2000. The order of accumulation of Metals in both soil and vegetables samples was $\mathrm{Fe}>\mathrm{Zn}>\mathrm{Mn}>\mathrm{Cu}>\mathrm{Ni}>$ $\mathrm{Pb}$.

Transfer factors for heavy metals from soil to vegetables: Table 4 show the Transfer Factor (TF) of $\mathrm{Cu}, \mathrm{Mn}, \mathrm{Fe}, \mathrm{Zn}, \mathrm{Ni}$ and $\mathrm{Pb}$ from soil to plant, which is one of the key components of human exposure to metals through the food chain. Transfer factors were determined to quantify the relative difference in bioavailability of metals to plants or to identify efficiency of plant species to accumulate a given metal. These factors were based on the root uptake of metals and discount the foliar absorption of atmospheric metal deposits. The degree of accumulation shows that $\mathrm{Zn}$ is higher than Fe.

The soil-plant transfer factor of different heavy metals shows the following order- TFZn> $\mathrm{TF}_{\mathrm{Fe}}>\mathrm{TF}_{\mathrm{Cu}}>\mathrm{TF}_{\mathrm{Ni}}>\mathrm{TF}_{\mathrm{Mn}}>\mathrm{TF}_{\mathrm{Pb}}$.

When table 1, 2, 3 were compared with the table 5 to access the concentration of heavy metals with reference to their permissible limits in water, soil, vegetables it was found that Fe and $\mathrm{Zn}$ were in very high conc. Presence of these metals in higher concentration than permissible limits given by IS/WHO/FAO ${ }^{15}$. The concentration of $\mathrm{Pb}$ and $\mathrm{Ni}$ was below detectable limits and concentration of $\mathrm{Cu}$ and $\mathrm{Mn}$ was slightly above the permissible limits.

\section{CONCLUSION}

The concentration of $\mathrm{Fe}$ and $\mathrm{Zn}$ in the soil samples were very high compared to the $\mathrm{WHO} /$ FAO maximum permissive limits while the concentrations of $\mathrm{Cu}$ and $\mathrm{Mn}$ were slightly above the permissible limits. The concentration of $\mathrm{Pb}$ and $\mathrm{Ni}$ were below the detection limits in soil. On the other hand in all the vegetables, the concentration of heavy metals was higher than the WHO/FAO permissible limits.

From the above study it was found that bioaccumulation of heavy metals in all the vegetables vary with the vegetable. The soil-plant transfer factor of different heavy metals shows the following order $-\mathrm{TF}_{\mathrm{Zn}}>\mathrm{TF}_{\mathrm{Fe}}>\mathrm{TF}_{\mathrm{Cu}}>\mathrm{TF}_{\mathrm{Ni}}>\mathrm{TF}_{\mathrm{Mn}}>\mathrm{TF}_{\mathrm{Pb}}$. The soil-plant transfer factor for $\mathrm{Cu}$ was highest in Chawli and spinach, TF of Mn was highest in Flower, TF of Fe was highest in Chawli, TF of Zn was highest in Bathua, TF of $\mathrm{Ni}$ was highest in Flower and spinach, TF of $\mathrm{Pb}$ was highest in Brinjal and Spinach.

\section{ACKNOWLEDGEMENT}

This study was sponsored through University grant commission (UGC), Delhi, India and Dr. Pravin Charde, Principal, Sevadal Mahila Mahavidyalaya, Nagpur for which the authors are extremely grateful.

\section{REFERENCES}

1. $\wedge$ "Nag River Basin".

2, $\quad$ "Heritage status for Nag river".

3. Yusuf, A. A., Arowolo, T. O. and Bamgbose, O., "Cadmium, Copper and Nickel levels in vegetables from industrial and residential areas of Lagos city, Nigeria", Global Journal of Environ Science, 1(1), 1 - 6 (2002).

4. H.K. Pandey*, Seema Gakhar and Gourav Chawla, Heavy metal toxicity in ground water of khajuwala area Located in bikaner division of western rajasthan, Curr World Environ , 1(1), 41-44 (2006).
5. John O. Jacob, Samuel E. Kakulu, Assessment of Heavy Metal Bioaccumulation in Spinach, Jute Mallow and Tomato in Farms within Kaduna Metropolis, Nigeria. American Journal of Chemistry, 2(1): 13-16 (2012).

6. Vandana Parth, N.N. Murthy and Praveen Raj Saxena, Assessment of heavy metal contamination in soil around hazardous waste disposal sites in Hyderabad city (India): natural and anthropogenic implications, E3 Journal of Environmental 
Research and Management , 2(2). pp. 027034, (2011).

7. Amiya Tirkey, P. Shrivastava and A. Saxena, Bioaccumulation of Heavy Metals in Different Components of two Lakes Ecosystem, Curr World Environ , 7(2), 293-297 (2012)

8. S.A. lqbal and H.C. Kataria, Study of heavy metal contamination in Halali Dam water of Vidisha District near Bhopal (M.P.) India with reference to human health, Curr World Environ, 1(1), 61-64 (2006).

9. O.D. Opaluwa, M. O. Aremu, L. O. Ogbo, J. I. Magaji, I.E. Odiba and E.R. Ekpo, Assessment of Heavy Metals in Water, Fish and Sediments from UKE Stream, Nasarawa State, Nigeria, Curr World Environ , 7(2), 213220 (2012).

10. Sumantrao B. Bikkad and Sunil R. Mirgane, Assessment of heavy metals in ground water of Aurangabad Industrial areas, Curr World Environ , 3(1), 131-134 (2008).

11. Kachenko, A. G. and Singh, B., "Heavy metals contamination in vegetables grown in urban and metal smelter contaminated sites in Australia", Water, Air and Soil Pollution, 169, 101 - 123 (2006).

12. U.A. Awode, A. Uzairu, M.L. Balarabe, G.F.S. Harrisson and O.J. Okunola, Assessment of Peppers and Soils for Some Heavy Metals from Irrigated Farmlands on the Bank of River Challawa, Northern Nigeria.

13. Sharma, R. J., Agrawal, M. and Marshall, F. M., "Heavy metals in vegetables collected from production and market sites of a tropical urban area of Indian", Food and Chemical Technology, 47, 583 - 591 (2009).

14. APHA, Standard Methods for the Examination of Water and Wastewater. 16th Edition. American Public Health Association. New York (1992).

15. FAO/WHO, Codex Alimentarius Commission. Food additives and contaminants. Joint FAO/ WHO Food Standards Programme, ALINORM 01/12A, pp:1-289 (2001). 